\title{
SLAVENSKI KORIDOR U ČEŠKIM PLANOVIMA STVARANJA BEDEMA PROTIV NJEMAČKOG DRANG NACH OSTEN
}

\author{
Janko Bekić \\ Ministarstvo obrane \\ Republike Hrvatske \\ E-mail: janko.bekic@morh.hr
}

https://doi.org/10.20901/an.18.16

Pregledni rad

Zaprimljeno 10. 11. 2021.

Prihvaćeno 26. 11. 2021.

\begin{abstract}
Sažetak Izbijanjem Prvoga svjetskoga rata, češko vodstvo u egzilu započinje diplomatsku borbu za uspostavu neovisne čehoslovačke države koja je trebala biti u bliskom savezništvu sa zapadnim silama Antante. Svjesni nepovoljnog geostrateškog položaja buduće države, češki lideri Masaryk i Beneš od samoga početka projekt uspostave neovisne Čehoslovačke vezuju uz stvaranje neovisne Poljske i južnoslavenske države. U tom kontekstu barataju i s idejom Slavenskog koridora koji bi preko zapadne Ugarske - naseljene Nijemcima, Mađarima, ali i gradišćanskim Hrvatima - trebao spojiti dvije slavenske države i onemogućiti obnavljanje Austro-Ugarske, ali i spriječiti daljnji njemački Drang nach Osten. Na temelju teorije strukturalnog realizma, rad proučava ideju koridora u ratnoj fazi, kada je inicijativa u rukama češke političke emigracije, te u fazi Pariške mirovne konferencije, kada inicijativu preuzima "Velika četvorka". Rad nastoji pružiti odgovor na pitanje je li Slavenski koridor predstavljao jedan od temeljnih zahtjeva političkih predstavnika Čehoslovačke ili je korišten kao pregovarački alat za ostvarenje važnijih geopolitičkih ciljeva.
\end{abstract}

Ključne riječi Prvi svjetski rat, Pariška mirovna konferencija, geopolitika, Čehoslovačka Republika, Kraljevina Srba, Hrvata i Slovenaca, Slavenski koridor

\section{Uvod: češko vodstvo i strukturalni realizam u "srcu Srednje Europe"1}

Na stotu obljetnicu pripajanja Gradišća (Burgenland), a samim tim i gradišćanskih Hrvata, ${ }^{2}$ Republici Austriji (5. prosinac 1921. godine) valja se prisjetiti pomalo zaboravljene, ali zanimljive geopolitičke ideje češkog vodstva u egzilu da se nakon

\footnotetext{
Rad je preoblikovano i dorađeno poglavlje magistarskog rada obranjenog 2006. godine na Sveučilištu u Beču. Za razliku od magistarskog rada, koji se temom Slavenskog koridora bavio u kontekstu raspada Austro-Ugarske i nastanka Čehoslovačke, ovaj rad ideju koridora obrađuje iz perspektive teorije međunarodnih odnosa, točnije strukturalnog realizma, čime se nastoji rasvijetliti jedan specifični pokušaj geopolitičkog rješavanja sigurnosne dileme u kojoj se nakon 1918. našla novonastala Čehoslovačka Republika.

2 Gradišćanski Hrvati (Burgenlandkroaten) potomci su Hrvata iz Like, Krbave, zapadne Bosne, Korduna i Banovine koji u 16. stoljeću bježe pred Osmanlijama i nastanjuju se na prostoru zapadne Ugarske koja je također ispražnjena zbog učestalih upada Turaka.
} 
očekivanog poraza Centralnih sila u Prvome svjetskome ratu na prostoru današnjeg Gradišća, a tadašnje zapadne Ugarske, ustroji tzv. Slavenski koridor. Uspostavljen na etnički mješovitom području naseljenom Nijemcima, Mađarima i Slavenima (prije svega Hrvatima), koridor je trebao imati trostruku ulogu: 1) zaustaviti perenijalno germansko "Nadiranje prema Istoku" (Drang nach Osten), 2) onemogućiti ponovno stvaranje osovine Beč-Budimpešta na štetu slavenskih naroda Srednje Europe i 3) osigurati kopnom okruženoj Čehoslovačkoj izlaz na Jadransko more.

Prva polovica 20. stoljeća predstavlja razdoblje neupitnog primata geopolitike učenja o uzajamnom djelovanju zemljopisnih i političkih datosti. Velika većina tadašnjih državnika fokusirana je na ostvarenje (ili zadržavanje) povoljnih državnih granica, u kojima vidi osnovni preduvjet rješavanja svih političkih i gospodarskih problema. Drugim riječima, najviše značaja pridaje se lokaciji - povoljnosti položaja, veličini teritorija, prirodno-geografskim činiocima, kontroli strateških točaka, rasporedu kopna, mora i strateških resursa (Zorko, 2018: 17-18). Ključni pojmovi toga razdoblja su: životni prostor (Lebensraum), izlaz na more, barijera, bedem, cordon sanitaire, koridor i sl. U vrijeme održavanja Pariške mirovne konferencije 1919.-1920. smatralo se da država bez dodira s morem i bez teritorijalne povezanosti sa saveznicima nije ekonomski sigurna, što - u najgorem slučaju - može dovesti u pitanje njezinu samoodrživost.

Ova su pitanja morila i češko vodstvo u domovini i egzilu u vrijeme Velikoga rata. Dotad uglavnom austroslavistički ${ }^{3}$ nastrojeni političari u ljeto 1914. godine najvećim dijelom napuštaju ideju reforme i reorganizacije Habsburške Monarhije te se okreću ideji stvaranja čehoslovačke nacionalne države s teritorijem i stanovništvom koji bi joj omogućili da se uspješno odupre više nego izglednim njemačkim, austrijskim i mađarskim pretenzijama. S obzirom na nepovoljan geostrateški položaj planirane države - gotovo potpuna okruženost povijesnih čeških zemalja njemačkim (austrijskim) teritorijem, uz prisutnost brojne njemačko-govorne manjine u rubnim dijelovima Češke (Böhmen) i Moravske (Mähren), te ugroženost slovačkog etničkog područja mađarskim nastojanjima da očuvaju jedinstvo Zemalja Krune sv. Stjepana - češko vodstvo u egzilu projekt stvaranja neovisne Čehoslovačke uvijek je promatralo u širem kontekstu, povezujući svoje planove sa stvaranjem neovisne Poljske na sjeveru i južnoslavenske države na jugu.

Iz tog razloga, primarni fokus ovoga rada je na djelovanju češkog vodstva u egzilu koje je poveznicu s Južnim Slavenima vidjelo kao važan faktor u osiguranju opstanka nove države. Gradišćanski Hrvati u ovoj su epizodi puki objekt povijesnih zbivanja, a čak se i najistaknutiji hrvatski članovi Jugoslavenskog odbora s puno rezerve odnose prema ideji koridora. Sekundarni fokus rada je na stavovima Francuske, Velike Britanije, Sjedinjenih Američkih Država i Italije koje su imale presudan utjecaj na poslijeratno uređenje Europe. Iz toga proizlazi da je za ovaj rad važna geopolitika, koju Halford Mackinder opisuje kao "utrku za moć među državama na objedinjenoj pozornici svijeta". Mackinderov naglasak na "odnose moći odozgo, gdje veliki igrači, ili scenaristi, povlače poteze i razmještaju manje važne likove" (Mackinder u: Zorko, 2018: 33-34) posebno je prikladan za razdoblje Pariške mirovne konferencije, kada su četvorica svjetskih lidera - Georges Clemenceau, David Lloyd George, Woodrow Wilson i Vittorio Emanuele Orlando - više-manje samostalno iscrtali granice poslijeratne Europe, pa tako i novostvorene Čehoslovačke.

Austroslavizam - politika koja je težila rješavanju nacionalnog pitanja slavenskih naroda unutar Habsburške Monarhije, putem trijalizma ili federalizacije (Cipek, 2004: 602-603). 
Geopolitički pristup naglašava da politička prevlast nije samo pitanje moći u smislu ljudskih i materijalnih resursa, nego i geografskog konteksta u kojem se ta moć ispoljava (Sloan i Gray, 1999: 2). U geopolitici je geografski faktor presudan, jer je poimanje prijetnje prvenstveno određeno zemljopisnom udaljenosti i terenom (Sheehan, 2005: 22). U slučaju povijesnih čeških zemalja, jasna je prvorazredna važnost geografije, a samim tim i geopolitike - Češka, Moravska i južni dio Šleske su između dva svjetska rata gotovo u potpunosti okružene njemačkim i austrijskim teritorijem, što je bez imalo sumnje vrlo nepovoljan položaj za novostvorenu državu s brojnom njemačko-govornom manjinom. Stoga je nastojanje Praga da Čehoslovačku politički i vojno poveže s Poljskom i Kraljevinom SHS prije svega geopolitički projekt. Nadalje, inzistiranje čehoslovačke delegacije na Pariškoj mirovnoj konferenciji da se pod svaku cijenu sačuvaju povijesne granice čeških zemalja nije bila samo želja za očuvanjem njihovog integriteta, nego i dio strateške procjene da bi gubitkom Češke šume (Böhmerwald), Rudne gore (Erzgebirge) i Sudetskog gorja (Sudetengebirge), gorskih lanaca koji se svi nalaze u pograničnoj zoni, Čehoslovačka bila beznadno izložena potencijalnoj njemačkoj agresiji, bez ikakve šanse da se obrani. ${ }^{4}$ I drugi su bili svjesni nezavidnog položaja čeških zemalja. Poljski državnik Roman Dmowski 1925. na tu je temu napisao:

Položaj Češke je nevjerojatno opasan. To opasniji što je njezina geografska i politička granica od glavnoga njemačkog prostora, Češki masiv, prestala biti i jezična granica. Nijemstvo se prelilo preko tih planina i široko zaposjelo padine $s$ češke strane. Štoviše, Češka na jugu ima ozbiljnog neprijatelja u Mađarskoj, koja je u posljednjih pola stoljeća postala najvjerniji saveznik Njemačke. Mi na opasnost njemačke poplave koja ugrožava Čehe ne možemo ostati ravnodušni. Dok šlesko rame nijemstva, Legnica-Wroclaw, ima s druge strane negermaniziran češki prostor, dotle je njegova snaga relativna, pa stoga i pritisak nijemstva na nas ne može imati veliku udarnu snagu... Dodat ću da za Čehe postojanje Poljske ima neusporedivo veće značenje. Ako mi ne bismo opstali na zapadu, Česi ne bi mogli egzistirati kao narod. Postali bi slavenski otok u njemačkom moru kao što su Lužički Srbi (Dmowski, 1998: 139).

Jednako tako, geopolitička su promišljanja ta koja su nagnala vodstvo nove države da na mirovnoj konferenciji u Parizu službeno zatraži inkorporiranje dvaju područja naseljena nečeškim i neslovačkim stanovništvom - sjeverne polovice Slavenskog koridora (južna polovica trebala je biti dodijeljena Kraljevini SHS) i Zakarpatja, naseljenog Rusinima, koje je trebalo osigurati kontakt s Kraljevinom Rumunjskom.

Zbog srodnosti geopolitike s teorijom strukturalnog realizma (neorealizma), ovaj rad kao teorijsku osnovicu uzima djela Kennetha Waltza Čovjek, država i rat (Waltz, 1998) i Theory of International Politics (Waltz, 2010). Waltz prednost daje samoj strukturi međunarodnog sistema anarhije koja strukturalno uvjetuje i determinira ponašanje aktera. Temeljni teorijski zaključak neorealizma je da u anarhiji, odnosno u nedostatku naddržavnog arbitra, države balansiraju jedna prema drugoj, važući i kalkulirajući moć one druge. To može značiti da će se pojedini akteri "priključiti lokomotivi" (bandwagoning), tj. vodećoj državi ili državi pobjednici te nastojati na taj način povećati svoje dobitke (slabe države posebno su sklone ovakvom pristupu). Postoje i "balanseri" koji pokušavaju smanjiti rizike zajedničkim suprotstavljanjem nekoj snažnijoj sili (Donnelly, 2013: 44-45).

4 To se pokazalo potpuno točnim kada je Njemački Reich u ožujku 1939. godine - bez ispaljenog metka - okupirao "Ostatak Češke" ("Resttschechei") koji je opstao nakon potpisivanja Münchenskog sporazuma u rujnu 1938. 
Čehoslovački lideri Masaryk i Beneš primjenjivali su upravo ova dva pristupa: između 1914. i 1918. priključili su svoju zemlju (tada tek u nastajanju) francuskoj lokomotivi, procijenivši da je Francuska izgledni ratni pobjednik, ali i država koja ima najveći interes podržati čehoslovačke zahtjeve. Nakon završetka rata i uspostave neovisne Čehoslovačke, Masaryk i Beneš okreću se balansiranju, odnosno pokušaju stvaranja srednjo- i istočnoeuropskog saveza (bez sudjelovanja Austrije i Mađarske) koji bi se mogao uspješno suprotstaviti njemačkom revizionizmu. Naime, Njemačka je Versajskim mirovnim ugovorom znatno oslabljena, međutim, njezino istočno susjedstvo je raspadom Ruskog Carstva i Habsburške Monarhije razlomljeno u niz malih i srednje velikih država (Kleinstaaterei) koje su s pravom strahovale da bi mogle postati metom njemačkog ekspanzionizma.

Još jedan strukturalni realist - John Mearsheimer - pripadnike ove škole dijeli na defenzivne i ofenzivne realiste. Defenzivni realisti smatraju da je pokušaj ostvarenja hegemonije ili nadmoći kontraproduktivan, jer će sustav prije ili kasnije kazniti one koji pokušavaju prisvojiti suviše moći. Nasuprot njima, ofenzivni realisti drže da je maksimalizacija moći sasvim razuman pristup jer je posjedovanje nadmoći najbolji način osiguravanja opstanka države (Mearsheimer, 2013: 88). U kontekstu istraživanog slučaja, rad je bliži interpretaciji da su se Čehoslovačka i njezin glavni mentor Francuska ponašali u skladu s postulatima defenzivnog realizma, jer nakon 1918. nisu težili hegemoniji, nego su tražili načine kako spriječiti Njemačku da ostvari nadmoć na europskom kontinentu. Međutim, pokušaj uspostave koridora preko Gradišća mogao bi se interpretirati i kao ofenzivna mjera s ciljem ostvarenja slavenske hegemonije u Srednjoj Europi i osiguranja opstanka Čehoslovačke Republike. Mađarski povjesničar Oscar Jászi je reorganizaciju Srednje Europe nakon 1918. tumačio kao pokušaj Francuske da popuni vakuum sile i preuzme njemačku hegemoniju u Srednjoj i Jugoistočnoj Europi (Hanák, 1998: 269).

Treba naglasiti kako kod Masaryka i Beneša pronalazimo i elemente liberalnog svjetonazora, kao i sklonost Wilsonovim idejama o "pravednom miru" i o potrebi osnutka Lige naroda koja bi mirnim putem rješavala sporove među državama. Međutim, krhkost preteče Ujedinjenih naroda ${ }^{5}$ i vezanost Čehoslovačke uz Francusku, koja je preferirala obnovu ravnoteže moći, usmjerili su čehoslovačko vodstvo prema traženju rješenja u duhu strukturalnog realizma.

U metodološkom smislu, rad je utemeljen na analizi sekundarnih i primarnih izvora, koji su dobrim dijelom pronađeni u stručnim bibliotekama (povijest, pravo, slavistika) Sveučilišta u Beču. To se odnosi i na tri zemljovida priložena ovom tekstu.

Priča o Slavenskom koridoru smještena je u samo srce Srednje Europe - geografski, kulturni i politički prostor koji je u 20. stoljeću prolazio kroz nekoliko faza usitnjavanja i okrupnjivanja, da bi se na koncu našao objedinjen unutar Europske unije. Među hrvatskim politolozima, težište na proučavanje ovog dijela Europe stavio je Tihomir Cipek, koji je istraživao germanske ideje Mitteleurope (Cipek, 1997), projekt Podunavskog saveza država i naroda (Cipek, 2000), odnos Masaryka prema krizi Europe (Cipek, 2003) i ideju Srednje Europe Františeka Palackog (Cipek, 2004). Kada govorimo o istraživanjima posvećenima Pariškoj mirovnoj konferenciji

\footnotetext{
"Kada se sagleda sveukupna međuratna povijest Lige naroda, konačan rezultat njenog djelovanja su poraz i promašaj... Tijekom Prvog svjetskog rata glavni nosioci ideje liberalnog poretka bili su Velika Britanija i SAD. Budući da se zbog pobjede izolacionističke politike i povlačenja Wilsona 1921. godine SAD povukao iz novouspostavljenih svjetskih struktura, duhovnim predvodnikom novog liberalnog poretka ostala je samo Velika Britanija, koja je od samih početaka imala rezerve po pitanju razine do koje novi liberalni poredak treba nadomjestiti onaj stari hobbesovski, temeljen na realpolitici i ravnoteži snaga" (Popović, 2012: 81).
} 
i nestabilnom međunarodnom poretku koji je iz nje proizašao, trebamo spomenuti radove Livie Kardum, posebno njezinu knjigu Suton stare Europe. Europska diplomacija i Prvi svjetski rat (Kardum, 2009). Ovaj rad navedena istraživanja nastoji nadopuniti boljim shvaćanjem političkih prilika u Srednjoj Europi tijekom Prvoga svjetskoga rata i u vrijeme održavanja Pariške mirovne konferencije. Posebno želi dodatno osvijetliti diplomatsko djelovanje novonastalih država i njihovih najvažnijih predstavnika i povezati materiju političke povijesti s teorijama međunarodnih odnosa.

Što se ranije objavljenih radova o Slavenskom koridoru tiče, valja spomenuti znanstveni rad povjesničarke Božene Vranješ-Šoljan - "Pitanje takozvanog gradišćanskog koridora - hrvatsko gledište" - u kojem je obrađen onaj aspekt Slavenskog koridora koji ovdje nije u središtu pažnje, a odnosi se na stajališta hrvatskih političara i medija prema ideji stvaranja poveznice između Čehoslovačke i Kraljevine SHS. Tako ćemo kod Vranješ-Šoljan doznati da je ideja o koridoru rođena u prvoj etapi idejnog povezivanja praških i zagrebačkih sveučilištaraca, poznatijih kao pripadnika Napredne omladine. Doznat ćemo i to da je Stjepan Radić pred kraj 1918. postao gorljivi zagovornik spajanja novostvorenih slavenskih država, a za neuspjeh ovog projekta optuživao je unitarističko-centralističke snage u Kraljevini SHS koje su odmah nakon ujedinjenja pokazale da neće tolerirati nikakvu samostalnu političku akciju iz Hrvatske. Najzanimljiviji dio rada odnosi se na stavove samih gradišćanskih Hrvata, koji su - po svemu sudeći - velikom većinom podržavali ostanak Gradišća u Mađarskoj te su se jednako protivili podjeli svojih krajeva između Čehoslovačke i Kraljevine SHS, kao i pripajanju Austriji (Vranješ-Šoljan, 1992: 76-82). Valja napomenuti da se autorica, među ostalim, poziva na raniji rad povjesničara Bogdana Krizmana "Gradišće na Pariškoj mirovnoj konferenciji 1919-1920." (Krizman, 1974).

\section{Češka borba za neovisnost i ideja Slavenskog koridora od 1914. do 1918.}

Već navedeno odustajanje čeških lidera od politike austroslavizma u ljeto 1914. godine nije označilo automatsko formiranje ujedinjenog češkog fronta s ciljem stvaranja neovisne čehoslovačke države. Umjesto toga dolazi do podjele unutar češkog korpusa na desno-konzervativni lager koji teži bliskim vezama s carskom Rusijom, i centrističko-progresivni koji budućnost Čehoslovačke vidi u savezništvu sa zapadnim silama, prije svega Francuskom i Velikom Britanijom.

Karel Kramár, vodeći političar proruskog tabora, odmah nakon izbijanja rata počinje javno zagovarati stvaranje Velikoslavenskog Carstva od Tihog oceana do Baltičkog i Jadranskog mora (v. Kartu 1). ${ }^{6}$ Carstvo, zamišljeno u obliku federacije, trebalo je uključivati rusku, poljsku, češku (ne čehoslovačku), srpsku (ne srpsko-hrvatsku ili jugoslavensku), crnogorsku i bugarsku državu. Pritom Kramář prvi spominje koridor preko zapadne Ugarske kojim bi se spojile češka i srpska komponenta (Falk, 1938: 28-29).

Tomáš Masaryk se, kao vodeća ličnost prozapadne opcije, protivio panslavenskim idejama, a posebno je kritičan prema autoritarnom vodstvu carske Rusije. Odbacivao je čistu politiku moći, a rješavanje nacionalnih pitanja malih naroda vidio je u sklopu nove demokratske Europe, utemeljene na ravnopravnosti država (Perman, 1962: 14-15 i Gajan, 1971: 26-27). Za razliku od Masaryka, koji je u jesen 1914. go-

6 O panslavenskim tendencijama u češkim zemljama prije 1914., v. Bradley (1961) i Vyšný (1977). 


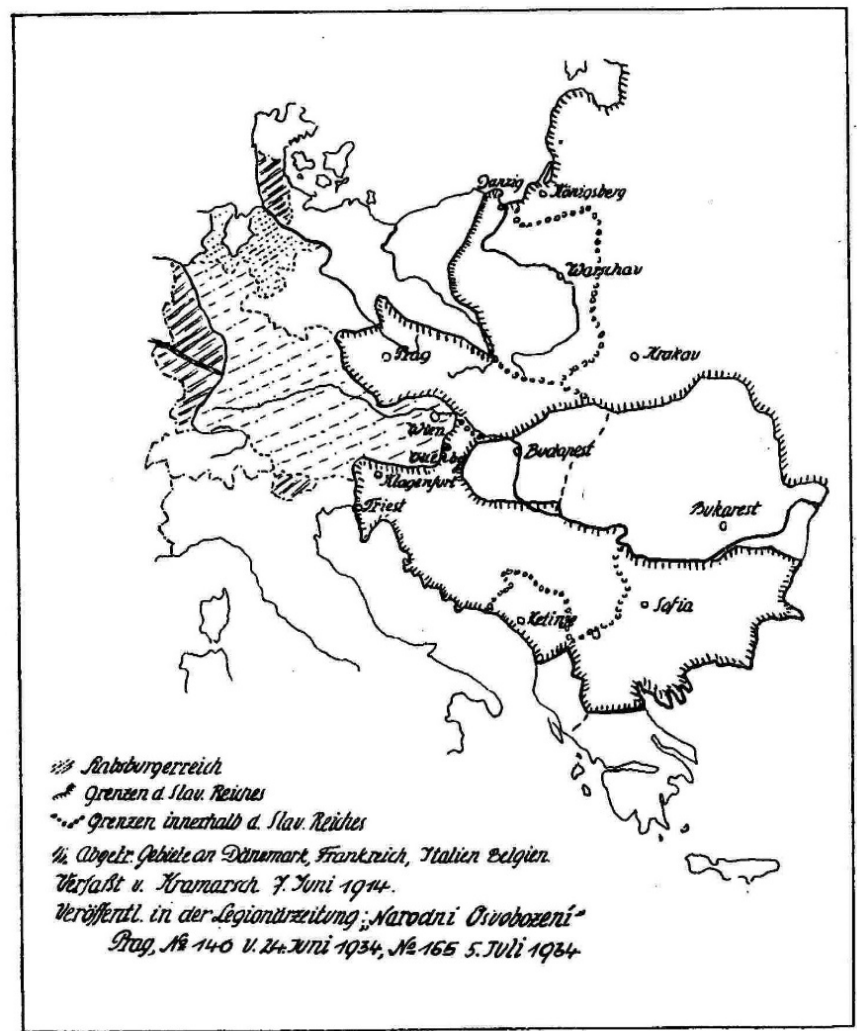

Karte des Slavischen Reiches von Kramarsch.

\section{Karta 1.}

Kramářovo Slavensko Carstvo. Izvor: Falk, 1938.

dine otišao u egzil, Kramář ostaje u Češkoj, gdje u svibnju 1915. biva uhićen i osuđen zbog veleizdaje; a u zatvoru se nalazi do pomilovanja u srpnju 1917. Činjenica da se Masaryk u ključnim godinama Velikoga rata nalazi na slobodi te se neometano kreće između Pariza, Londona i Rima, dok Kramáŕ čami u austrijskom zatvoru, dovela je do prevage prozapadnog političkog usmjerenja i uskog vezivanja češkog nacionalnog pokreta uz Francusku i Veliku Britaniju (Perman, 1962: 23).

Pojedini povjesničari zastupaju tezu da se Austro-Ugarska nije raspala iznutra - zbog neriješenog nacionalnog pitanja slavenskih naroda, Rumunja, Talijana i dr. - nego je razbijena izvana. Vjerojatno najpoznatiji među njima, François Fejtö, smatra da je Masaryk svojom humanističkom retorikom zapravo vješto prikrivao makijavelistički pristup politici, ostvarivši na taj način vrlo brzo značajan utjecaj u prijestolnicama Zapadne Europe. Posebno je Francuska bila prijemčiva za Masarykovu ideju stvaranja niza ili lanca neovisnih slavenskih država na europskom istoku i jugoistoku, koje bi služile kao brana njemačkom ekspanzionizmu (Fejtö, 1993: 355-362). Uvidjevši da će Francuska bezrezervno podržati češka nastojanja, Masaryk se 1916. godine prebacuje u Veliku Britaniju, dok u Parizu ostavlja svog najbližeg suradnika Edvarda Beneša da vodi i upravlja djelatnostima Čehoslovačkog nacionalnog vijeća. 
Masaryka u Londonu dočekuje manje entuzijastična britanska politička elita, čiji je primarni interes osujetiti daljnji rast Njemačke i vratiti status quo ante bellum. Međutim, Masaryk i u Londonu pronalazi vrlo utjecajne saveznike, prije svega urednika vanjskopolitičke sekcije lista The Times Henrya Wickhama Steeda, dugogodišnjeg prijatelja češkog političkog emigranta i velikog zagovornika neovisnosti slavenskih naroda Habsburške Monarhije. Steedovim angažmanom utjecajni The Times postaje glasilo slavenskih pokreta za neovisnost (Zeman, 1971: 350). Pored toga, Masaryk pokreče politički magazin programatskog naziva The New Europe u kojem objavljuje mnoštvo vlastitih tekstova. Kako je tisak već onda znatno utjecao na javno mnijenje u Velikoj Britaniji, političko se klatno također počelo primicati zahtjevima češkog vodstva u egzilu (May, 1996: 23-27). Ukratko, možemo kazati da su Masarykovi planovi reorganizacije Srednje Europe na stolove britanskih decision-makera došli okolnim putem - preko medija.

Češko propagandno djelovanje našlo se pred najvećim izazovom u Italiji. Tamošnji političari i dobar dio javnosti u vrijeme Velikoga rata ${ }^{7}$ gaje snažne antislavenske sentimente (koji će se ubrzo nakon rata, pod vodstvom Benita Mussolinija, manifestirati u obliku otvorenog i eksplicitnog rasizma). Iako je spomenuti antislavizam u Italiji primarno okrenut protiv Slovenaca i Hrvata, koji čvrsto brane austro-ugarske položaje na rijeci Soči, on se u širem smislu odnosi na sve Slavene, posebno u kontekstu njihove potencijalne navale na Jadransko more, shvaćeno među Talijanima kao mare nostrum. Iz tog razloga češki egzilanti u Rimu neće polučiti značajnije rezultate, ovoga puta ni preko skromne podrške koju će pružiti redakcije tiskovina $\mathrm{Il}$ Secolo, Corriere della Sera i Popolo d'Italia (Fejtö, 1993: 363).

Češko vodstvo u egzilu našlo se pred posebno kompleksnim zadatkom u Sjedinjenim Američkim Državama, koje su se tek u travnju 1917. godine uključile u ratna zbivanja. Naime, predsjednik Wilson je do zadnje godine rata vjerovao u mogućnost i potrebu očuvanja Austro-Ugarske, uz provođenje unutrašnjeg preustroja koji bi slavenskim i drugim narodima osigurao visok stupanj autonomije i samouprave, ali ne i pravo na samoopredjeljenje (Kardum, 1988: 134-135). Wilson je svoje prijedloge za pravedno okončanje rata najjasnije formulirao u "Četrnaest točaka" objavljenima 8. siječnja 1918. One su, u dijelu koji se odnosio na Habsburšku Monarhiju, predstavljale znatno odstupanje od već osigurane podrške Francuske i Velike Britanije za uspostavu neovisne Čehoslovačke i veliki problem za češke i slovačke emigrantske krugove u SAD-u. Međutim, do svibnja 1918. postaje jasno da se Austro-Ugarsku neće moći odvojiti od Njemačke i da separatni mir s Habsburzima nije ostvariv. S tim na umu, Wilson postepeno mijenja stav i na koncu nevoljko pristaje na disoluciju Austro-Ugarske, čime je njezina sudbina definitivno zapečaćena (Prinz, 1971: 103-105).

Što se samog Slavenskog koridora tiče, Masaryk u travnju 1915. godine, dakle u vrijeme kada se u Londonu sklapa tajni ugovor s Kraljevinom Italijom, britanskom ministru vanjskih poslova Sir Eduardu Greyu osobno predaje memorandum u kojem se spominje i geografska poveznica buduće čehoslovačke i "srpsko-hrvatske" države preko pojasa na zapadnoj granici Ugarske. Masaryk u njemu objašnjava da na spomenutom području živi značajna hrvatska manjina te da bi koridor između dviju država imao veliko vojno značenje, a osim toga bi bitno olakšao njihovu ekonomsku

\footnotetext{
Italija u travnju 1915. godine prelazi na stranu Antante nakon što su joj tajnim Londonskim ugovorom obećana znatna proširenja teritorija na štetu Austro-Ugarske. Od hrvatskih područja Italiji su pritom obećane Istra, sjeverna Dalmacija te svi otoci osim Krka, Raba, Čiova, Šolte i Brača.
} 
suradnju. Masaryk posebno ističe da bi ovaj koridor predstavljao "slavenski bedem" protiv njemačkog marša na Carigrad-Bagdad (Falk, 1938: 30-33).

Valja istaknuti da Masaryk još od prosinca 1914. raspolaže studijom o Hrvatima u zapadnoj Ugarskoj. Studiju, koja uključuje skicu mogućeg koridora i precizne statistike o hrvatskim selima na tom području, izradio je Ivan Lorković - zastupnik u Hrvatskom saboru i stari Masarykov prijatelj iz praških studentskih dana (Schlag, 2001: 242). Masaryk je u vezi koridora tražio podršku Jugoslavenskog odbora, s čijim je članovima tijekom rata više puta izravno komunicirao u Rimu. No, iako je među članovima Odbora postojao određeni interes za uspostavom koridora, najvažnija ličnost među njima - Ante Trumbić - pokazao se skeptičnim. Štoviše, Trumbić je precizno nabrojao pro i contra argumente u vezi ovog češkog zahtjeva:

\begin{tabular}{|c|c|c|}
\hline Pro: & - & $\begin{array}{l}\text { izravna prometna povezanost između Čeha, Slovaka i Južnih } \\
\text { Slavena; samim tim olakšana trgovinska razmjena bez prelaže- } \\
\text { nja austrijskih i mađarskih carinskih granica; } \\
\text { mogućnost uspostave trojnog saveza između Južnih Slavena, } \\
\text { Čehoslovaka i Poljaka; } \\
\text { sprečavanje njemačko-mađarske Srednje Europe (usp. Nau- } \\
\text { mannov plan }{ }^{8} \text { ) i kontrola kopnenog puta prema Orijentu; } \\
\text { mogućnost proširenja jadranskih luka Rijeka i Trst. }\end{array}$ \\
\hline
\end{tabular}

Contra: - povreda nacionalnog principa, jer u koridoru - La Marche slave - prema ugarskom popisu stanovništva iz 1910. živi 662.489 Mađara, 287.437 Nijemaca i samo 221.671 Južnih Slavena (Slovenaca i Hrvata). Doduše, slika bi se bitno promijenila pribrojavanjem mađariziranih i germaniziranih Južnih Slavena, jer ovdje živi više mađariziranih i germaniziranih, nego Mađara i Nijemaca;

- i Mađari i Nijemci stalno bi vršili politički pritisak na takav koridor;

- $\quad$ konačno, vojna obrana bi zbog tako dugih granica s Austrijom i Mađarskom bila izuzetno teška i izvediva jedino u savezu sa zapadnim silama (Suppan, 1996: 564).

Iz navedenog se može zaključiti da su predstavnici čehoslovačke političke emigracije tijekom rata pokušavali zainteresirati hrvatsku stranu za uspostavu koridora preko pojasa u zapadnoj Ugarskoj, ali su u tome samo djelomično uspjeli, pa Slavenski koridor nikada nije postao službeni zahtjev Jugoslavenskog odbora. Suzdržanost hrvatske strane po ovom pitanju može se objasniti činjenicom da je Odbor u tom trenutku imao daleko većih briga; tu se prije svega misli na buduće razgraničenje $s$ Italijom, kao i na uređenje odnosa s Kraljevinom Srbijom, koja u prvim godinama rata još uvijek nije bila na čistu želi li uvećanu Srbiju ili zajedničku državu s Hrvatima i Slovencima. Dakako, postojao je i treći razlog - Hrvati bi i u slučaju ostvarenja

8 Friedrich Naumann u svojoj knjizi Mitteleuropa iz 1915. godine zagovara stvaranje srednjoeuropskog saveza država pod njemačkom dominacijom. Liberal Naumann pod snažnim je utjecajem socijaldarvinizma - učenja o borbi naroda i rasa za opstanak. Smatra da se njemački narod na početku 20. stoljeća nalazi u uzlaznoj fazi i da taj razvoj treba pratiti odgovarajuća ekspanzionistička vanjska politika (Cipek, 1997: 163-164). Zanimljivo je da se, unatoč ovakvim stavovima, vrlo bliskima kasnijem nacionalsocijalizmu, zaklada njemačkih liberala osnovana 1958. zove upravo prema njemu. 
maksimalističkih talijanskih teritorijalnih zahtjeva sasvim sigurno zadržali izlaz na Jadransko more, što je njihov ukupni geopolitički položaj činilo manje prekarnim od čehoslovačkog.

Češko vodstvo u egzilu s idejom Slavenskog koridora upoznalo je i američku te francusku javnost. Masaryk je 1916. godine predstavnicima češke i slovačke emigracije u SAD-u poslao zemljopisnu kartu s granicama buduće čehoslovačke države, a na njoj je bio ucrtan i Slavenski koridor. U prosincu iste godine, Beneš u Parizu objavljuje politički spis pod naslovom "Uništite Austro-Ugarsku!" (Détruisez l'Autriche-Hongrie!). U njemu objašnjava da će slobodni narodi Europe nakon završetka Velikoga rata morati nastaviti "ekonomsku borbu" protiv Njemačke, a to će jedino biti moguće u slučaju izgradnje nepremostivog "slavenskog bedema" istočno od nje. Ovaj bedem svoju bi funkciju mogao ispuniti jedino u slučaju povezivanja Čeha, Slovaka i Južnih Slavena putem Slavenskog koridora (Falk, 1938: 34).

Slavenski koridor se spominje i u najvažnijem Masarykovom uratku objavljenom u vrijeme rata, u knjizi iz 1918. "Nova Europa. Slavensko gledište" (The new Europe. The Slav standpoint):

Neki češki i jugoslavenski političari upućuju na mogućnost povezivanja Slovačke s jugoslavenskom državom: Područje uzduž ugarske granice s Austrijom nekoć je pripadalo Češkoj, Moravskoj i Slovačkoj; a trenutno je nastanjeno Nijemcima i djelomično Mađarima, međutim ondje žive i slovenske i hrvatske manjine. Ovo bi područje, u slučaju pripajanja njezinog sjevernog dijela Slovačkoj, a južnog dijela Jugoslaviji, međusobno povezalo Sjeverne i Južne Slavene. Imalo bi dužinu od otprilike 200 kilometara. Ovaj plan kao preduvjet ima potpunu pobjedu Saveznika; jer nema nikakve sumnje da ga Nijemci i Mađari nikada ne bi mirno prihvatili. U slučaju da dođe do stvarne demokratske rekonstrukcije Europe, egzistencija Sjevernih i Južnih Slavena bit će osigurana i bez ove poveznice (Masaryk, 1922: 103-104).

Formulacija s početka pasusa - "neki češki i jugoslavenski političari" - ukazuje na određeno ograđivanje Masaryka od ideje Slavenskog koridora, iako ju je on dotad gorljivo zastupao. Posljednja rečenica također relativizira neophodnost uspostave fizičke veze između Čehoslovaka i Južnih Slavena konstatacijom da ona neće biti potrebna ukoliko se poslijeratna Europa izgradi na demokratskim temeljima. Ovakav stav Masaryka pred kraj rata otvara pitanje je li Slavenski koridor ikada bio jedan od centralnih zahtjeva češkog vodstva u egzilu ili je služio kao pregovarački alat u ostvarenju vitalnih interesa buduće države - zadržavanja povijesnih granica čeških zemalja te iscrtavanja povoljnog razgraničenja između Slovaka i Mađara.

\section{Čehoslovački teritorijalni zahtjevi na Pariškoj mirovnoj konferenciji 1919.-1920.}

Jesen 1918. donijela je veliki preokret u ratnim zbivanjima. Centralne sile na svim su bojištima jedva držale borbene linije ili su se nalazile u povlačenju. Austro-Ugarska, vojno i gospodarski slomljena te politički beznadno podijeljena, bila je spremna na primirje. Car i kralj Karlo I. poduzima zadnji očajnički pokušaj spašavanja države objavom "Carskog manifesta" 16. listopada u kojem obećava federalizaciju monarhije na osnovama Wilsonovih "Četrnaest točaka". Samo dva dana kasnije, Masaryk odgovara objavom Deklaracije o neovisnosti čehoslovačke nacije. Tog istog 18. listopada, predsjednik Wilson u svom posljednjem communiquéu prema austro-ugarskoj vladi piše: 
Vlada Sjedinjenih Američkih Država priznala je postojanje ratnog stanja između Čeho-Slovaka te Njemačkog i Austro-Ugarskog Carstva, kao i to da je Čeho-Slovačko nacionalno vijeće de facto ratna vlada s punim autoritetom da rukovodi vojnim i političkim poslovima Čeho-Slovaka. ${ }^{9}$ (Vlada SAD-a) također je u cijelosti priznala opravdanost nacionalnih aspiracija Jugo-Slavena za slobodom... Predsjednik, stoga, više nije u mogućnosti prihvatiti puku "autonomiju" ovih naroda kao osnovu za mir (Perman, 1962: 52-53).

Ubrzo nakon toga, austro-ugarska vlada potpisuje primirje u Padovi, Karlo I. abdicira, a 12. studenog proglašena je Republika Njemačka Austrija (Republik Deutschösterreich), koja odmah u začetku polaže pravo na njemačka govorna područja u Češkoj, Moravskoj i Šleskoj. Čehoslovačka vlada već 28. listopada preuzima vlast u Pragu; Kramář postaje premijer, Beneš ministar vanjskih poslova, a Masaryk prvi predsjednik Čehoslovačke Republike. U tom trenutku jedino Francuska službeno podržava temeljni čehoslovački zahtjev za očuvanjem povijesnih granica čeških zemalja, dok Velika Britanija, SAD i Italija ovo pitanje žele riješiti na Mirovnoj konferenciji. Ne želeći ništa prepustiti slučaju, čehoslovačka vlada šalje vojsku u sporna područja nastojeći stvoriti fait accompli i prije samog početka Mirovne konferencije. London, Washington i Rim takav potez prihvaćaju kao provizorno rješenje, inzistirajući na raspravi o ovom pitanju na konferenciji u Parizu (Perman, 1962: 72-91).

I u slučaju slovačko-mađarskog razgraničenja, nova vlast u Pragu mogla se uzdati u francusku podršku. Nakon bilateralnog dogovora čehoslovačkog i francuskog ministarstva vanjskih poslova, pri čemu su u potpunosti ignorirane druge sile Antante, francuski maršal Ferdinand Foch uspostavio je vojnu demarkacijsku liniju iza koje su se mađarske snage morale povući. Ta je linija najvećim dijelom odgovarala Masarykovim zahtjevima iz vremena rata. Ukratko, možemo reći da je Čehoslovačka Republika još u prosincu 1918. godine, dakle prije početka Pariške mirovne konferencije, de facto ostvarila svoja dva najvažnija teritorijalna zahtjeva - nepovredivost povijesnih granica čeških zemalja i pripajanje slovačkog etničkog prostora koji se dotad nalazio u sastavu Ugarske (Perman, 1962: 91-96).

Mirovna konferencija u Parizu svečano je otvorena 18. siječnja 1919., na 48. obljetnicu osnivanja Njemačkog Carstva (18. siječnja 1871. u dvorcu Versailles), što je bila jasna poruka da se Njemačkoj sprema odmazda. Francuski primat se, osim u mjestu održavanja konferencije, ogledao i u činjenici da je njome predsjedao francuski premijer Clemenceau (Rothbarth, 1921: 17). Poslovnikom je utvrđeno da će vodeće pobjedničke sile (SAD, Velika Britanija, Francuska, Italija i Japan) sudjelovati na svim sjednicama i u svim komisijama, dok će ostale pobjedničke države prisustvovati samo onim sjednicama koje ih se izravno dotiču. U drugoj skupini zemalja, među ostalima su se našle Poljska, Rumunjska, Čehoslovačka i Srbija (Rothbarth, 1921: 107-109). ${ }^{10}$

Glavni organ konferencije bilo je Vijeće desetorice: po dva predstavnika SAD-a, Velike Britanije, Francuske, Italije i Japana. Ovo se tijelo uskoro podijelilo u Vijeće četvorice, poznatije kao "Velika četvorka": predsjednik SAD-a, te premijeri Velike

9 Čehoslovačka legija, sastavljena od dobrovoljaca i dezertera iz austro-ugarske vojske, u Prvome svjetskome ratu borila se na strani Antante, ponajviše u Rusiji, Francuskoj i Italiji.

10 Unatoč tome što je osnovana 1. prosinca 1918., Kraljevina Srba, Hrvata i Slovenaca nije priznata kao sudionica Pariške mirovne konferencije. Hrvatskim i slovenskim političarima i stručnjacima dozvoljen je pristup konferenciji, ali samo u svojstvu članova srbijanske delegacije. To se može smatrati relativnim diplomatskim uspjehom jer su Hrvati i Slovenci na ovaj način ipak uspjeli izbjeći stigmu i tretman ratnih gubitnika. 
Britanije, Francuske i Italije, i pomoćno Vijeće petorice: ministri vanjskih poslova SAD-a, Velike Britanije, Francuske, Italije i Japana (Almond i Lutz, 1935: 1-5).

S obzirom da ova tijela nisu imala vremena slušati i razmatrati zahtjeve svih država koje su se - na ovaj ili onaj način - našle na strani pobjedničkih sila, uspostavljene su specijalne komisije, sastavljene od stručnjaka, čiji je zadatak bio pažljivo razmotriti zahtjeve pojedinih država te izraditi preporuke o kojima bi se onda odlučivalo na najvišoj političkoj razini. Iako se uspostavom komisija nastojao ostaviti dojam depolitizacije i stručnog odlučivanja o kompleksnim temama poput povlačenja novih granica, njihovi članovi su ipak dobili političke smjernice kojih su se trebali maksimalno pridržavati. S druge strane, nije bilo nimalo jasno kojim se principima trebaju voditi oni čiji je zadatak bio iscrtati novu političku kartu Europe - je li to princip samoopredjeljenja, odnosno uvažavanje želja stanovništva na određenom području, princip poštivanja povijesnih granica ili princip održivosti država koji mora uzimati u obzir i ekonomske te strateške aspekte (Perman, 1962: 121-125).

Dvočlana delegacija Čehoslovačke (premijer Kramář i ministar vanjskih poslova Beneš) na mirovnu je konferenciju došla oboružana s jedanaest memoranduma. Za ovaj rad od najvećeg je značaja Memorandum br. 2 nazvan "Teritorijalni zahtjevi Čehoslovačke Republike". Oni su bili podijeljeni u sedam točaka: 1. Češka, Moravska i Šleska, 2. Korekcija granica Češke, Moravske i Šleske, 3. Slovačka, 4. Rusini u Ugarskoj, ${ }^{11}$ 5. Susjedstvo Čehoslovaka i Jugoslavena (v. Kartu 2), 6. Internacionalizacija prometnica i 7. Lužički Srbi i Čehoslovaci u Beču. U točki br. 5 konkretno se navodi:

1. Ukoliko se u Srednjoj Europi želi uspostaviti novi politički sustav, koji će garantirati dugotrajan mir, onda se Nijemce i Mađare mora razdvojiti, a između Čehoslovaka i Jugoslavena uspostaviti susjedstvo. Ovo nije lokalni problem Čeha ili Jugoslavena, ovo je europski problem. ${ }^{12}$

2. Da bi se ovo rješenje ostvarilo, potrebno je pripojiti četiri njemačko-mađarske županije zapadne Ugarske (Moson, Sopron, Vas i Zala) Čehoslovačkoj Republici i Jugoslaviji. [...]

Autori memoranduma su smatrali da primjena principa nacionalnosti, tj. samoopredjeljenja, nikada neće biti savršena i da će uvijek postojati nacionalne manjine u stranim državama. Dodaju kako je "u slučaju višeg interesa" opravdano žrtvovati određeni broj stanovnika ukoliko im se istovremeno osiguraju potrebne slobode. $\mathrm{Na}$ koncu je naglašeno kako čehoslovačka delegacija ne inzistira na uspostavi koridora, nego rješavanje ovog pitanja prepušta svim zainteresiranim stranama (Raschhofer, 1937: 34-67).

Južnoslavenska, službeno srbijanska, delegacija također je spomenula mogućnost uspostave Slavenskog koridora u memorandumu nazvanom "Jugoslavija u svjetlu statistike", kojeg je izradio docent za statistiku na Sveučilištu u Zagrebu te stručnjak južnoslavenske delegacije u Parizu Jozo Lakatoš (v. Kartu 3). Njegov spis je sadržavao i kartu Kraljevine SHS, s ucrtanim koridorom i preciznim podacima: površina koridora $1648 \mathrm{~km}^{2}, 148.168$ Nijemaca, 104.374 Južnih Slavena, 68.214 Mađara,

${ }_{11}$ Zahtjev za pripajanjem Zakarpatja pojavio se tek nakon Oktobarske revolucije 1917. Od tog trenutka, češko vodstvo je planirani "slavenski bedem" predstavljalo i kao branu prema širenju komunizma u smjeru zapada. Ugarski Rusini su zbog složene međunarodne situacije nakon završetka Prvoga svjetskoga rata podržali pripajanje svojeg etničkog prostora Čehoslovačkoj. O tome više u radu P. R. Magocsija The Ruthenian Decision to Unite with Czechoslovakia iz 1975.

12 Ovaj zahtjev je tipični strukturalni zahtjev radi sigurnosti. Očigledno je riječ o diskursu geostrateške teritorijalne raspodjele i uspostave nove poslijeratne ravnoteže u Europi. 


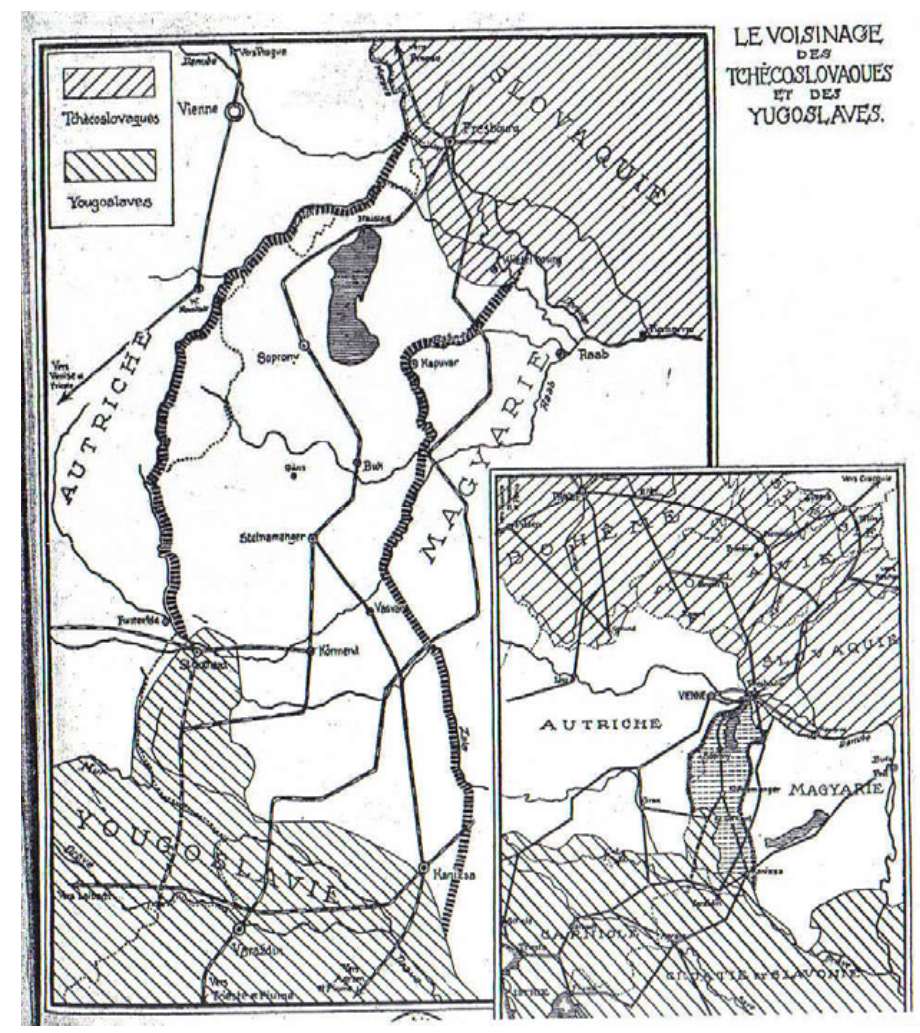

Karta 2.

Susjedstvo Čehoslovaka i Jugoslavena. Izvor: Raschhofer, 1937.

2.238 drugih Slavena i 2.179 ostalih. Ova uža verzija koridora imala je očiti cilj drastično smanjiti broj Mađara koji bi ostali živjeti na tome području, međutim ni ova mini-verzija Slavenskog koridora nije predstavljala službeni zahtjev južnoslavenske delegacije na mirovnoj konferenciji u Parizu (Falk, 1938: 67 i Lederer, 1963: 107).

Čehoslovački teritorijalni zahtjevi konačno su se počeli razmatrati 5. veljače 1919., kada je uspostavljena Komisija za čehoslovačke poslove. Komisija je imala osam članova. SAD su predstavljali Charles Seymour (kojeg je kasnije zamijenio Archibald C. Coolidge) i Allen W. Dulles, Veliku Britaniju Sir Joseph Cook i Harold Nicolson, Francusku Jules Cambon i Jules Laroche te Italiju markiz Giuseppe Salvago-Raggi i Augusto Stranieri.

Francuska je, kao jedina zemlja "Velike četvorke", imala izravnu granicu i dugu povijest ratovanja s Njemačkom. Stoga je gajila poseban interes da istočno od svog vječnog rivala stvori snažan i profrancuski nastrojen blok država. Iz tog razloga, Francuska je bila spremna udovoljiti svim zahtjevima čehoslovačke delegacije. Francuski članovi komisije imali su prednost domaćeg terena, a u korist im je išla i činjenica da je komisijom predsjedao Francuz Cambon. To je na koncu i dovelo do toga da su skoro svi teritorijalni zahtjevi Čehoslovačke Republike ispunjeni. Međutim, po pitanju Slavenskog koridora, Francuska je ostala sama (Perman, 1962: 133).

Talijanski članovi komisije najoštrije su se usprotivili ideji Slavenskog koridora jer su pod svaku cijenu nastojali izbjeći jačanje Kraljevine SHS kroz teritorijalnu vezu sa Čehoslovačkom. Kako je Italija u to vrijeme bila u sukobu s Austrijom oko Južnog 


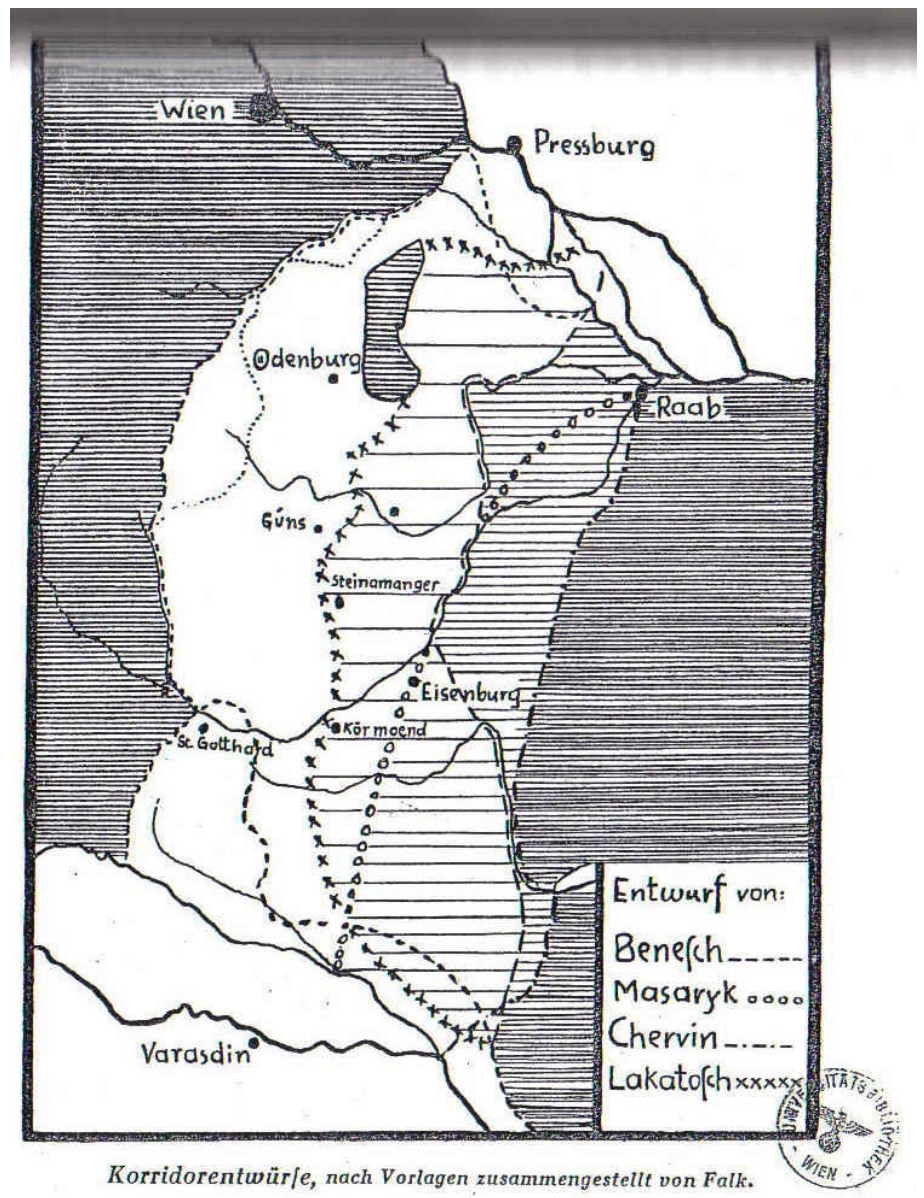

Karta 3.

Nacrti Slavenskog koridora (Beneš, Masaryk, Chervin i Lakatoš). Izvor: Falk, 1938.

Tirola, Salvago-Raggi i Stranieri smatrali su da je najbolje rješenje četiri zapadnougarske županije ostaviti Mađarskoj. Italija je u Mađarima općenito vidjela saveznike protiv Slavena te nije mogla dozvoliti slavensko okruživanje i izolaciju prijateljski nastrojene države. Iz istih pobuda, talijanski članovi komisije protivili su se i pripajanju Zakarpatja Čehoslovačkoj te su nastojali pomaknuti slovačko-mađarsku granicu što je više moguće prema sjeveru (Mayer, 1968: 679 i Perman, 1962: 146-148). ${ }^{13}$

Britanci nisu imali razrađene planove za Srednju Europu, koja im nikada nije bila u fokusu, nego su bili vođeni mišlju očuvanja balansa među europskim silama. U tom kontekstu, spajanje Slavena putem koridora činilo im se pregrubim narušavanjem statusa quo prije rata. Jedan od dvojice britanskih članova komisije - Nicolson

${ }^{13}$ Italija je Kraljevinu SHS i Čehoslovačku Republiku vidjela kao produžene ruke Francuske u istočnoj i jugoistočnoj Europi. Iskoristivši poljsko-češke razmirice oko Šleske i grada Cieszyna/Těšna, talijanska vanjska politika uspostavila je osovinu Budimpešta-Varšava, kao protalijansku protutežu okosnici Beograd-Prag. Ovakav razvoj stvari onemogućio je ispunjenje Masarykovog plana o trojnom savezu Poljske, Čehoslovačke i Jugoslavije. 
- još je krajem siječnja u svoj dnevnik zapisao: "Češka i Moravska, povijesna granica opravdana, iako to znači obuhvaćanje brojnih Nijemaca; Těšín, Šleska, Bohumín, opravdani; Slovačka, granica na Dunavu, nije opravdana u traženom opsegu; ugarski Rusini opravdani i poželjni; 'Lužički Srbi' čista glupost; 'koridor' prema Jugo-Slaviji potpuno neopravdan" (Nicolson, 1933: 252).

I dok su europske delegacije unutar komisije zauzimale pozicije koje su odgovarale njihovim nacionalnim interesima, jedino su američki predstavnici - čini se - tražili "pravedno rješenje". Svjesni opasnosti uključivanja velikog broja nezadovoljnih manjina u novostvorenu i demokratsku državu, američki članovi komisije pokušavali su svugdje gdje je to bilo moguće odvojiti manje komade teritorija, kako bi smanjili broj Nijemaca i Mađara u Čehoslovačkoj. Iz istog su se razloga izjasnili protiv ideje Slavenskog koridora, koji bi, prema njihovom shvaćanju, samo dodatno opteretio novu državu nezadovoljnim manjinama (Perman, 1962: 138-143).

Komisija za čehoslovačke poslove je 12. ožujka objedinila svoje zaključke u izvještaj koji je proslijeđen Središnjoj teritorijalnoj komisiji, a nakon njezinog odobrenja i Vijeću četvorice. Zaključci komisije glasili su: 1. Zadržavanje povijesnih granica Češke, Moravske i Šleske, osim u slučajevima Frýdlant (Friedland) i Aš (Asch) koje treba pripojiti Njemačkoj, i u slučaju regije oko Těšína (Cieszyn) čiju najistočniju općinu treba prepustiti Poljskoj; 2. Korekcija stare granice u regijama oko Ratibořa (Ratibor), Kladskog (Glatz), Cmunta (Gmünd) i Valtica (Feldsberg) u korist Čehoslovačke; 3. Priznavanje južne slovačke granice kako je zatraženo u memorandumu; 4. Pripajanje Zakarpatja Čehoslovačkoj Republici; 5. Odbijanje autonomije za Lužice (Lausitz) i 6. Odbijanje stvaranja Slavenskog koridora i upućivanje pitanja ekonomske komunikacije između Čehoslovačke Republike i Kraljevine Srba, Hrvata i Slovenaca komisiji za internacionalizaciju željeznica i vodenih puteva (Perman, 1962: 153-154).

Zaključci komisije 4. su travnja došli na dnevni red "Velike četvorke". Prvo su adresirana pitanja vezana za njemačko-čehoslovačku demarkaciju: Gradovi Frýdlant i Aš političkom odlukom ostavljeni su Čehoslovačkoj, a Ratiboř i Kladsko Njemačkoj. Pitanje Těšína - predmet sve oštrijeg poljsko-čehoslovačkog spora ostalo je neriješeno. Tek 12. svibnja riješeno je pitanje korekcije granice između Austrije i Čehoslovačke, na način da je potonja dobila dva uska pojasa kod Cmunta i Valtica. Granica između Čehoslovačke i Mađarske konačno je utvrđena 12. lipnja, na način da je "Velika četvorka" prihvatila preporuku komisije. Trzavice oko Těšína trajale su sve do kraja srpnja, kada je konačno utvrđena poljsko-čehoslovačka granica na rijeci Olše (Olza) koja grad dijeli na dva dijela (Perman, 1962: 169-272).

Francuska je odbijala prihvatiti preporuku komisije kojom se odbacuje zahtjev za uspostavom Slavenskog koridora te je u proljeće i ljeto 1919. i dalje nastojala uvjeriti ostale zemlje "Velike četvorke" u opravdanost čehoslovačkog zahtjeva. Međutim, za njih je stvar bila riješena i Saint-germainskim ugovorom od 10. rujna 1919. područje zapadne Ugarske s njemačko-govornom većinom prepušteno je Republici Austriji. ${ }^{14}$ Čehoslovačkoj strani se izašlo u susret na način da je jedna od dvije željezničke linije u smjeru juga ostavljena Mađarskoj, kako Austrija ne bi u cijelosti kontrolirala komunikaciju Čehoslovačke s Jadranom. Ovo rješenje imalo je i svoju vojno-stratešku pozadinu: u slučaju rata između Austrije i Čehoslovačke, potonja bi raspolagala že-

14 Ugovorom iz Saint-Germaina zabranjena je upotreba naziva Republika Njemačka Austrija te je Austriji zabranjeno pripajanje Njemačkoj (Anschlussverbot). 
ljezničkom linijom preko mađarskog teritorija. Isto tako, u slučaju mađarsko-čehoslovačkog sukoba, Čehoslovaci su mogli računati na prometnu vezu preko Austrije (Falk, 1938: 79).

Prije nego što je Gradišće moglo biti i službeno pripojeno Austriji pobjedničke sile morale su prvo potpisati mirovni ugovor s Mađarskom, što je ostvareno Trianonskim ugovorom od 4. lipnja 1920. Međutim, više od godinu dana kasnije Gradišće je još uvijek bilo pod mađarskom kontrolom, što je dovelo do rasta nervoze na austrijskoj strani. Krajem kolovoza 1921. Beč šalje žandarmeriju u sporno područje, no njezino napredovanje ubrzo je zaustavljeno od strane neregularnih mađarskih postrojbi. Između Austrije i Mađarske izbija mali rat koji će trajati tri mjeseca. Čehoslovačka u ovoj situaciji vidi još jednu (posljednju) šansu za uspostavom koridora te otvoreno prijeti slanjem vojske ukoliko velike sile ništa ne poduzmu (Falk, 1938: 90-92).

Italija je ovu prijetnju shvatila vrlo ozbiljno te se nametnula kao medijator ne bi li osujetila čehoslovačku vojnu intervenciju u spornom području. Sazvana je konferencija u Veneciji, a Austrija je pod pritiskom sila Antante 13. listopada 1921. morala pristati na održavanje plebiscita u gradu Sopronu (Ödenburg). U studenom je započelo povlačenje mađarskih milicija i postepeno preuzimanje Gradišća od strane austrijske Savezne vojske. Konačno, 5. prosinca 1921. svečano je proglašeno pripajanje Burgenlanda Austriji (Falk: 1938). ${ }^{15}$ Ovim činom definitivno je pokopana ideja Slavenskog koridora, a gradišćanski Hrvati postali su državljani Republike Austrije. ${ }^{16}$

Neuspjeh čehoslovačkog vodstva po pitanju Slavenskog koridora i sve veći animozitet između Praga i Varšave nisu odvratili Masaryka i Beneša od traganja za trojnim savezom koji bi odvratio potencijalne agresore. Drugim riječima, ostali su posvećeni pronalaženju geopolitičkog rješenja za čehoslovačku sigurnosnu dilemu. Tako je u kolovozu 1920. dogovoren politički i vojni savez između Čehoslovačke Republike i Kraljevine SHS, a čehoslovački ministar vanjskih poslova isti je oblik savezništva ponudio i Rumunjskoj, s kojom je Čehoslovačka preko Zakarpatja bila direktno povezana. Rumunjska vlada je na početku bila suzdržana, ali ju je neuspjeli pokušaj habsburške restauracije u Mađarskoj u travnju 1921. potaknuo da promijeni mišljenje. Rumunjski ministar vanjskih poslova Tache Ionescu u travnju i lipnju 1921. potpisao je ugovore s Čehoslovačkom i Kraljevinom SHS, čime je stvorena tzv. Mala Antanta - politička i vojna alijansa koja je tri države, djelomično ili u cijelosti proizašle iz bivše Austro-Ugarske, trebala zaštiti od mađarskog revizionizma i eventualnih daljnjih pokušaja habsburške restauracije (Ádám, 2004: 196-198).

\section{Umjesto zaključka: od Slavenskog koridora do Inicijative triju mora}

Izbijanje Prvoga svjetskoga rata u ljeto 1914. godine nagnalo je relevantne političke grupacije u češkim zemljama da rješavanje češkog (i slovačkog) nacionalnog pitanja potraže izvan Austro-Ugarske. Uhićenjem panslavenski nastrojenog

15 Plebiscit u Sopronu održan je 14. prosinca 1921. pod paskom savezničkih trupa sastavljenih od Talijana, Francuza i Britanaca. Unatoč njemačko-govornoj većini, žitelji Soprona su se opredijelili za ostanak u Mađarskoj, a saveznički generali su 1. siječnja 1922. grad prepustili mađarskim vlastima (Nouzille, 1987: 33-34).

${ }^{16}$ Gradišćanski Hrvati su danas jedna od šest priznatih manjinskih zajednica u Republici Austriji. 
Kramářa 1915. godine, inicijativa prelazi u ruke Masaryka i Beneša, koji se nalaze u svojevoljnom političkom egzilu te buduću čehoslovačku državu vide u bliskom savezništvu sa zapadnim silama, prije svega Francuskom i Velikom Britanijom. Kombinacijom izravnih kontakata s vladama sila Antante te vještim utjecajem na javno mnijenje putem prijateljski nastrojenih medija, češka politička emigracija brzo uspijeva uvjeriti većinu aktera na Zapadu u neodrživost Habsburške Monarhije i u potrebu osnivanja neovisnih država Poljske, Čehoslovačke i Jugoslavije, koje bi u budućnosti trebale služiti kao brana njemačkom ekspanzionizmu prema Istoku. Upravo je angažman Masaryka i Beneša za ispunjenje nacionalnih aspiracija Poljaka i Južnih Slavena te ostalih malih naroda Europe, a ne samo Čeha i Slovaka, izazvao simpatije i naklonjenost zapadne javnosti, što je uvelike utjecalo i na same donosioce političkih odluka - u konačnici i na američkog predsjednika Wilsona, koji je još početkom 1918. godine zagovarao (samo) unutarnju reformu Austro-Ugarske.

Završetkom rata i početkom rada Pariške mirovne konferencije, inicijativa prelazi u ruke lidera pobjedničkih sila i njihovih predstavnika u komisijama koje su imale zadatak razmotriti teritorijalne zahtjeve novonastalih država i izraditi preporuke na osnovu kojih su članovi "Velike četvorke" trebali donijeti konačne odluke. U ovoj fazi dolazi do eklatantnog razmimoilaženja u stavovima predsjednika Wilsona, koji teži pravednoj rekonstrukciji Europe i polaže sve nade u ideju Lige naroda, i premijera Francuske, Italije i Velike Britanije koji novu političku kartu Europe nastoje iscrtati u skladu s interesima država koje predstavljaju. Tako Francuska zauzima izrazito pročehoslovački stav, podržavajući sve teritorijalne zahtjeve Praga, uključujući i onaj o stvaranju Slavenskog koridora prema Kraljevini SHS. Italija, s druge strane, pokušava na sve moguće načine opstruirati čehoslovačke planove, u kojima vidi veliku opasnost za svoju ambiciju ostvarivanja hegemonije na Jadranskome moru. Veliku Britaniju, po običaju, ponajviše zanima balans snaga na kontinentu, zbog čega ne želi dozvoliti pretjerano jačanje niti jednoga bloka. U tom nastojanju ipak je bliža svojoj staroj saveznici Francuskoj, pa joj pomaže da Čehoslovačkoj osigura maksimalno povoljne granice, izuzev Slavenskog koridora.

$\mathrm{Na}$ ovome mjestu valja pokušati odgovoriti na pitanje je li Slavenski koridor prema Kraljevini SHS doista bio jedan od središnjih zahtjeva čehoslovačkog vodstva ili je služio kao pregovarački alat za ispunjenje drugih, važnijih zahtjeva poput očuvanja povijesnih granica Češke, Moravske i Šleske te povoljnog razgraničenja između Slovaka i Mađara. S jedne strane, čehoslovačko vodstvo je između 1914. i 1921. više puta iznosilo zahtjev za uspostavom teritorijalne veze između Južnih i Sjevernih Slavena. ${ }^{17}$ Valja naglasiti i to da je Masaryk u nekoliko navrata tražio podršku Jugoslavenskog odbora za navedeno rješenje. Čak i nakon odbijanja zahtjeva za uspostavom Slavenskog koridora na Pariškoj mirovnoj konferenciji, Prag je u jesen 1921. zaprijetio vojnom intervencijom u spornom području ukoliko zapadne sile ne zaustave oružani sukob Austrije i Mađarske oko Gradišća.

S druge strane, dva krucijalna dokumenta za razumijevanje materije Slavenskog koridora daju naslutiti da se on ne može smatrati jednim od temeljnih zahtjeva čehoslovačkog vodstva. U knjizi Nova Europa. Slavensko gledište iz 1918. Masaryk piše kako će u slučaju "stvarne demokratske rekonstrukcije Europe, egzistencija Sjevernih i Južnih Slavena biti osigurana i bez ove poveznice". U memorandumu "Terito-

17 Poljaci, Česi i Slovaci su Zapadni Slaveni, pa ovu formulaciju treba shvatiti kao pojednostavljenje namijenjeno nedovoljno upućenoj publici Zapadne Europe. 
rijalni zahtjevi Čehoslovačke Republike", koji je korišten kao službeni dokument na Pariškoj mirovnoj konferenciji, u vezi Slavenskog koridora piše: "Čehoslovaci ne inzistiraju na ovom rješenju ... i prepuštaju odluku svim zainteresiranim stranama". Mogući zaključak je da su čehoslovački lideri u prvim godinama rata gorljivo zastupali ideju Slavenskog koridora, ali su se s vremenom "ohladili" nakon što je postalo jasno da među vodećim silama jedino Francuska podržava ovakvo rješenje, da su Južni Slaveni samo rubno zainteresirani za ovaj projekt, a da se Poljaci uopće ne vide u trojnom savezu sa Čehoslovačkom i Jugoslavijom. ${ }^{18}$

Nakon što je postalo jasno da od Slavenskog koridora neće biti ništa, čehoslovačko vodstvo osmišljava novi plan te preko jednog drugog koridora - Zakarpatja, naseljenog Rusinima - povezuje Čehoslovačku, Rumunjsku i Kraljevinu SHS u tzv. Malu Antantu. Ova nova politička i vojna alijansa trebala je očuvati srednjoeuropski poredak stvoren na Pariškoj mirovnoj konferenciji. Njezin neuspjeh da to učini tema je za neki drugi rad.

Činjenica da neuspjeh uspostave Slavenskog koridora nije označio kraj čehoslovačkih pokušaja da se teritorijalnim povezivanjem sa saveznicima osiguraju od njemačke i mađarske prijetnje opravdava naglasak rada na geopolitici. Isto tako, zamjena prvotne ideje o trojnom savezu Čehoslovačke, Poljske i Kraljevine SHS s onom koja je dovela do osnutka Male Antante pokazuje da je Prag bio dosljedan u pokušajima balansiranja nasuprot Njemačke kao potencijalnog hegemona, što je u skladu s korištenom teorijom strukturalnog realizma. Ovaj rad nastojao je iz perspektive teorije međunarodnih odnosa rasvijetliti malo poznato geopolitičko i strateško pitanje ravnoteže snaga u Srednjoj Europi tijekom i nakon Prvoga svjetskoga rata. Primjenom strukturalne perspektive neorealizma pokazuje se specifični značaj Slavenskog koridora, kao koncepta koji je bio razmatran u planovima poslijeratnog uravnoteživanja snaga u Europi.

$\mathrm{Na}$ koncu, valja istaknuti kako Mala Antanta i neuspjeli pokušaj stvaranja trojnog saveza Čehoslovačke, Poljske i Kraljevine SHS nisu tek povijesni kurioziteti. Kao teritorijalno najfragmentiraniji dio kontinenta, Srednja Europa je bila i ostala plodno tlo za formiranje raznih političkih, ekonomskih, pa i obrambenih asocijacija. Nakon završetka hladnoga rata, tijekom kojega je najveći dio Srednje Europe bio prisilno vezan uz Sovjetski Savez putem Varšavskog pakta, na tom području nastaje čitav niz regionalnih saveza. Kronološkim redom, osnivaju se Višegradska skupina (1991.), Srednjoeuropski ugovor o slobodnoj trgovini (1992.), Salzburški forum (2000.), Srednjoeuropska obrambena suradnja (2010.), Inicijativa tri mora (2015.), Lublinski trokut (2020.) i dr. Niti jedna od navedenih organizacija nije isključivo slavenska ili germanska. Također, sve se trude dati do znanja da nisu okrenute ni protiv Njemačke, ni protiv Rusije. Ono što im je zajedničko je da nastoje okupiti male i srednje velike države srednjo-europskog prostora u forume koji bi trebali omogućiti usuglašavanje stavova i grupno zastupanje zajedničkih interesa; pogotovo unutar EU, kojom nakon "Brexita" dominiraju dvije države članice - ekonomski moćna Njemačka i (nuklearna) vojna sila Francuska.

Hrvatska u ovom smislu nije neaktivna, a u slučaju Inicijative tri mora, zajedno s Poljskom, čak je preuzela vodeću ulogu u toj političkoj platformi. Međutim,

18 Poljski maršal i šef države od 1918. do 1922. Józef Piłsudski gajio je ideju obnavljanja Poljsko-Litavske Unije, koja bi objedinila prostor između Baltičkog i Crnog mora (odatle i naziv Międzymorze ili Intermarium). Poput Masarykovog trojnog saveza Poljske, Čehoslovačke i Jugoslavije i ovaj je geopolitički projekt trebao spriječiti njemački ekspanzionizam prema Istoku, te širenje boljševizma prema Zapadu. 
još uvijek pokazuje određenu suzdržanost prema snažnijem povezivanju s drugim srednjoeuropskim državama. To je rezultat nastojanja hrvatskog političkog vodstva da stekne naklonost mahom zapadnoeuropskih zemalja osnivačica Unije. Pritom je upravo francuski stručnjak za geopolitiku Pierre Béhar još 1992. Hrvatsku smjestio u zamišljenu srednjoeuropsku federaciju zajedno s Poljskom, Češkom, Slovačkom, Austrijom, Mađarskom i Slovenijom (Béhar, 1992: 80-81). Hoće li ovo najprirodnije okruženje Hrvatske doživjeti i neki oblik političke integracije (unutar EU), pokazat će vrijeme pred nama. 


\section{Literatura}

Ádám, M. (2004). The Versailles System and Central Europe. Farnham: Ashgate.

Almond, N., i Lutz, R. H. (1935). The Treaty of St. Germain. A Documentary History of Its Territorial and Political Clauses. Stanford University: University Press.

Béhar, P. (1992). Une géopolitique pour l'Europe. Vers une nouvelle Eurasie? Pariz: Éditions Desjonquères.

Bradley, J. F. N. (1961). Czech Pan-Slavism Before the First World War. The Slavonic and East European Review, (40)94, 184-205.

Cipek, T. (1997). Mitteleuropa. Prilog povijesti germanskih ideja Srednje Europe do 1919. godine. Politička misao, (34)1, 154-166.

Cipek, T. (2000). Politički sustav "Podunavskog saveza država i naroda". Srednjeeuropska ideja Stjepana Radića. Radovi Zavoda za hrvatsku povijest, (32-33)1, 231240.

Cipek, T. (2003). Tomáš Garrigue Masaryk i kriza Europe. Politička misao, (40)3, 145-154.

Cipek, T. (2004). Ideja Srednje Europe Františeka Palackog. Časopis za suvremenu povijest, (36)2, 597-607.

Dmowski, R. (1998). Poljsko pitanje i preustroj Srednje Europe. U: J. Le Rider (ur.), Mitteleuropa (str. 117-152). Zagreb: Barbat.

Donnelly, J. (2013). Realizam. U: D. Jović (ur.), Teorije međunarodnih odnosa. Realizam (str. 39-66). Zagreb: Politička kultura.

Falk, E. (1938). Das Burgenland im Blickfeld tschechischer Großherrschaftspläne. Stuttgart: W. Kohlhammer.

Fejtö, F. (1993). Histoire de la destruction de l'Autriche-Hongrie. Requiem pour un empire défunt. Paris: Seuil.

Gajan, K. (1971). Masaryk, Beneš und Kramář und ihre Einflussnahme auf die Gestaltung der Friedensverträge. U: K. Bosl (ur.), Versailles-St. Germain-Trianon. Umbruch in Europa vor fünfzig Jahren (str. 25-48). München: Oldenbourg.

Hanák, P. (1998). Razmatranje ideje Srednje Europe. U: J. Le Rider (ur.), Mitteleuropa. (str. 261-272). Zagreb: Barbat.

Kardum, L. (1988). Američki stavovi o jadranskom pitanju uoči Pariške mirovne konferencije. Politička misao, (25)3, 132-145.

Kardum, L. (2009). Suton stare Europe, Europska diplomacija i Prvi svjetski rat. Zagreb: Golden marketing.

Krizman, B. (1974). Gradišće na Pariškoj mirovnoj konferenciji 1919-1920. Nastava povijesti, 4, 32-42.

Lederer, I. J. (1963). Yugoslavia at the Paris Peace Conference. A Study in Frontiermaking. New Haven: Yale University Press.

Magocsi, P. R. (1975). The Ruthenian Decision to Unite with Czechoslovakia. Slavic Review, (34)2, 360-381. https://doi.org/10.2307/2495193

Masaryk, T. G. (1922). Das neue Europa: der slavische Standpunkt. Berlin: C. A. Schwetschke \& Sohn.

May, E. R. (1996). Public Opinion. U: S. F. Wells Jr. i P. B. Smith (ur.), New European Orders, 1919 and 1991 (str. 18-40). Washington: Woodrow Wilson Center Press. 
Mayer, A. J. (1968). Politics and Diplomacy of Peacemaking. Containment and Counterrevolution at Versailles 1918-1919. London: Weidenfeld \& Nicolson.

Mearsheimer, J. J. (2013). Strukturalni realizam. U: D. Jović (ur.), Teorije međunarodnih odnosa. Realizam (str. 87-104). Zagreb: Politička kultura.

Nicolson, H. (1933). Peacemaking 1919. London: Constable.

Nouzille, J. (1987). La nouvelle frontière entre l'Autriche et la Hongrie (1919-1921). U: P. Ayçoberry, J-P. Bled i I. Hunyadi (ur.), Les Conséquences des Traités de Paix de 1919-1920 en Europe Centrale et Sud-Orientale (str. 23-34). Strasbourg: Association des Publications près les Universités de Strasbourg.

Perman, D. (1962). The Shaping of the Czechoslovak State. Diplomatic History of the Boundaries of Czechoslovakia, 1914-1920. Leiden: E. J. Brill.

Popović, P. (2012). Prijepori u teorijama međunarodnih odnosa. Zagreb: Politička kultura.

Prinz, F. (1971). Die USA und die Gründung der ČSR. U: K. Bosl (ur.), Versailles-St. Germain-Trianon. Umbruch in Europa vor fünfzig Jahren (str. 93-110). München: Oldenbourg.

Raschhofer, H. (1937). Die tschechoslowakischen Denkschriften für die Friedenskonferenz von Paris 1919/1920. Berlin: C. Heymanns Verlag.

Rothbarth, M. (1921). Die großen Vier am Werk. Beiträge zur Geschichte der Friedenskonferenz. Berlin: Deutsche Verlagsgesellschaft für Politik und Geschichte.

Schlag, G. (2001). Aus Trümmern geboren: Burgenland 1918-1921. Eisenstadt: Burgenländisches Landesmuseum.

Sheehan, M. (2005). International Security. An Analytical Survey. Boulder i London: Lynne Rienner Publishers.

Sloan, G., i Gray, C. S. (1999). Why Geopolitics? U: C. S. Gray i G. Sloan (ur.), Geopolitics, Geography and Strategy (str. 1-13). London: Frank Cass.

Suppan, A. (1996). Jugoslawien und Österreich 1918-1938. Bilaterale Außenpolitik im Europäischen Umfeld. München: Oldenbourg.

Vranješ-Šoljan, B. (1992). Pitanje takozvanog gradišćanskog koridora - hrvatsko gledište. Radovi Zavoda za hrvatsku povijest, (25)1, 73-84.

Vyšný, P. (1977). Neo-Slavism and the Czechs 1898-1914. Cambridge: Cambridge University Press.

Waltz, K. N. (1998). Čovjek, država i rat. Zagreb: Barbat.

Waltz, K. N. (2010). Theory of International Politics. Long Grove: Waveland Press.

Zeman, Z. (1971). A Diplomatic History of the First World War. London: Weidenfeld \& Nicolson.

Zorko, M. (2018). Geopolitika i teritorijalnost. Zagreb: Jesenski i Turk. 


\section{The Slavic Corridor in Czech Plans of Creating a Bulwark Against the German Drang nach Osten}

Summary After the outbreak of World War I, the exiled Czech leadership began its diplomatic quest for the establishment of an independent Czechoslovak state that was to become a close ally of Western Entente powers. Fully aware of the adverse geostrategic position of their future state, Czech leaders Masaryk and Beneš coupled the project of establishing an independent Czechoslovakia with the creation of an independent Poland and South Slavic state. In this context, they were considering the idea of a Slavic Corridor that would connect Czechoslovakia with Yugoslavia through a passageway in Western Hungary - an area populated by Germans, Magyars and Croats. The erection of the Corridor would neutralize the threat of an Austro-Hungarian restoration and hinder Germany's advance towards the East (Drang nach Osten). Based on structural realism theory, the paper explores the idea of the Corridor during the war phase, when the initiative is in the hands of Czech political émigrés, and in the phase of the Paris Peace Conference, when the initiative is seized by the "Big Four". The paper attempts to resolve the question whether the Slavic Corridor was a central demand of Czechoslovak representatives or if it was used as a negotiation tool for the attainment of more important geopolitical goals.

Keywords World War I, Paris Peace Conference, geopolitics, Czechoslovak Republic, Kingdom of Serbs, Croats and Slovenes, Slavic Corridor

Kako citirati članak / How to cite this article:

Bekić, J. (2021). Slavenski koridor u češkim planovima stvaranja bedema protiv njemačkog Drang nach Osten, Anali Hrvatskog politološkog društva, 18(1), 369389. https://doi.org/10.20901/an.18.16 